\title{
NOTES RELATING TO THE FLORA OF BHUTAN: XVII Zingiberaceae
}

\author{
R. M. SMITH
}

\begin{abstract}
A new species of Hedichium. H. griersonianum, is described and its relationship to $H$. ellipticum discussed. Two new combinations are made in Stahliamthus, S. intolucratus (King ex Baker) R. M. Snith, for which a lectotype is selected, and S. andersonii (Baker) R. M. Smith.
\end{abstract}

Hedychium griersonianum R. M. Smith, species nova H. elliptico Ham. ex J. E. Smith ob folia elliptica, ligulam rubram et bracteas unifloras similis, sed inflorescentia magis elongata, floribus multo minoribus, et anthera rubra differt. Fig.1A.

Leafy shoots c. $1 \mathrm{~m}$ tall. Leaves subsessile or very shortly petiolate, $30-35 \times 8-10 \mathrm{~cm}$, elliptic acuminate, glabrous. Ligule red, $1 \mathrm{~cm}$ long, membranous, entire, pubescent centrally on back; sheaths glabrous. Inflorescence drooping, c.12 $\times 6 \mathrm{~cm}$, elliptic, main axis pubescent; bracts green, imbricating, $1-2 \times 0.5-0.8 \mathrm{~cm}$, oblong acute with prominent hyaline margins, each subtending a single flower; bracteoles $1 \mathrm{~cm}$ long, tubular. Flowers cream; calyx $2-2.5 \mathrm{~cm}$ long, obscurely 3 -dentate and lightly pubescent at apex; corolla tube $3.5 \mathrm{~cm}$ long; lobes $2.5-3 \mathrm{~cm}$ long, linear, acute; lateral staminodes $1.5 \mathrm{~cm}$ long, $0.2-0.3 \mathrm{~cm}$ at the widest part, unguiculate, limb narrowly elliptic; labellum $1 \mathrm{~cm}$ long or a little more, unguiculate in lower, limb $0.4 \mathrm{~cm}$ wide, elliptic, bilobed in upper $\frac{1}{3}$; filament $2.5-3 \mathrm{~cm}$ long; anther crimson, $0.6-1 \mathrm{~cm}$ long; stigma cilate at mouth; style linear, hidden in a groove in filament which continues within corolla; ovary pubescent. Fruit unknown.

Type: S Bhutan: Sarbhang district, Sarbhang-Chirang rd, $19 \mathrm{~km}$ above Sarbhang, 26 $57^{\prime} 90^{\circ} 14^{\prime} \mathrm{E}, 1100 \mathrm{~m}$, steep rocky slope in hot forest, flowers fragrant, perianth cream, 1 vi 1979. Grierson \& Long 1547 (holo. E).

\section{Additional material seen:}

S BHUTAN: Chukka district, Marichong 'Mirichoma', 3500', scented, yellow, 3 vii 1914, Cooper 1152.

This species is dedicated to the late Mr A. J. C. Grierson, senior author of the Flora of Bhutan.

In the vegetative state it is impossible to distinguish $H$. griersonianum from $H$. ellipticum (Fig. IB), and the drooping inflorescence with its imbricating bracts is also common to both species. H. griersonianum differs in the more elongate inflorescence, considerably smaller flowers (those of $H$. ellipticum may be up to $15 \mathrm{~cm}$ long) which, except for the crimson anther, are uniformly cream throughout, and in the more shortly exserted corolla tube. Cooper 1152 deviates in the entirely glabrous ligule. 


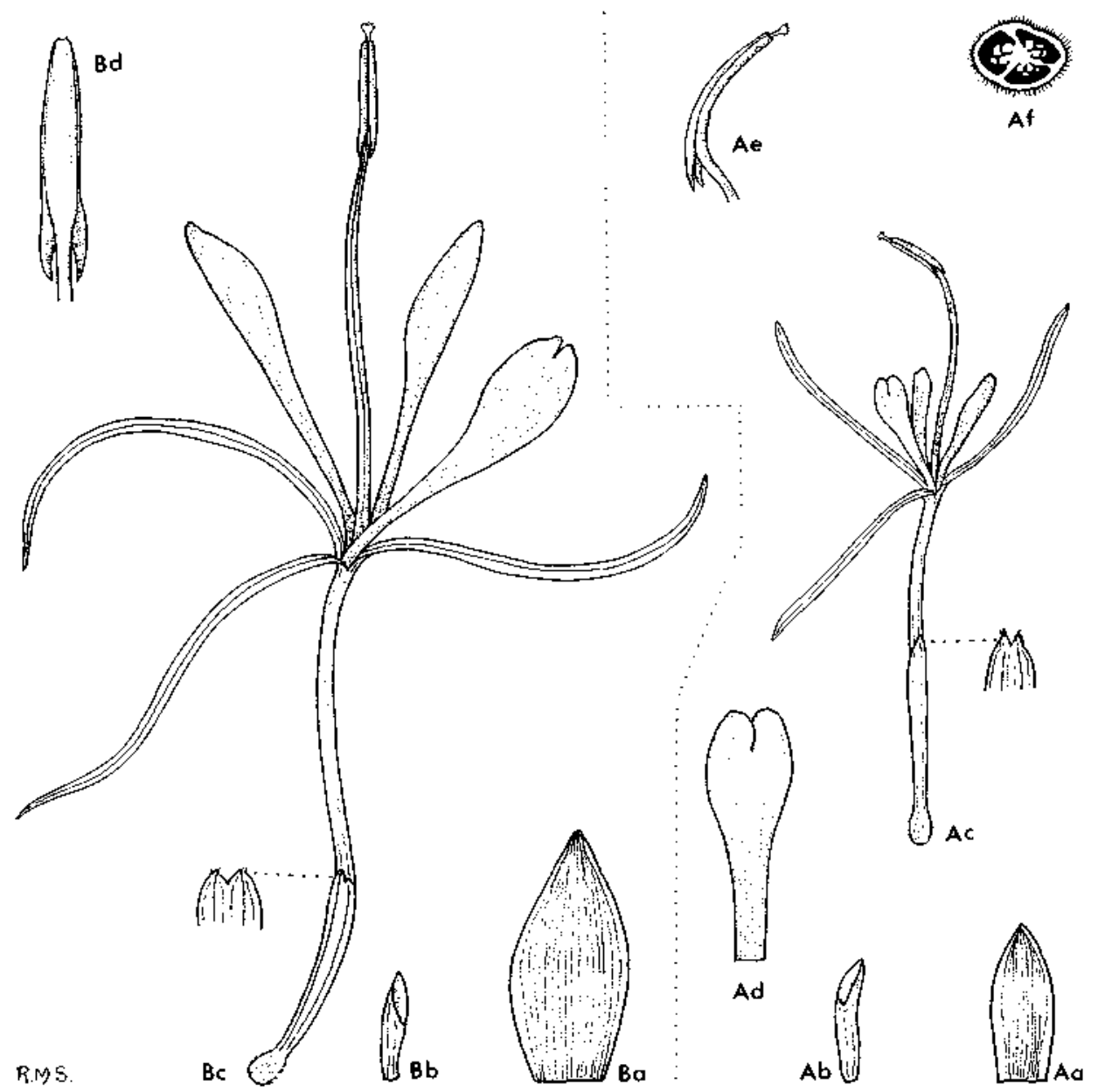

FIG. 1. A. Hedychium griersonicmum R. M. Smith: Aa, bract x 1; Ab, bracteole x 1; Ac, flower x 1; Ad, labellum x 3: Ae. anther from the side x 2; Af. ovary in T.S. x 4. B. H. ellipticum Ham. ex Smith: Ba, bract $\mathrm{x} 1$; $\mathrm{Bb}$, bracteole $\mathrm{x} 1$; Be, flower $\mathrm{x} 1$; Bd, anther from the rear $\mathrm{x} 2$. All from spirit material. A, Grierson \& Long 1547: B, Grierson \& Long 2160.

Stahlianthus invoiucratus (King ex Baker) R. M. Smith, comb. nov.

Basionym: Kaempferia involucrata King ex Baker in Hook.f., Fl.Brit.Ind. 6:231 (1890). Lectotype (selected here): Darjeeling; Rangirum, 1877, Hort. Calcutta Jaffray s.n. (K). Also in Assam; Jenkins s.n. (n.v.).

Stahlianthus andersonii (Baker) R. M. Smith, comb. nov.

Basionym: Kaempferia andersonii Baker in Hook.f., Fl.Brit.Ind. 6:321 (1890).

Type: Burma, Hort. Calcutta, Anderson s.n. (CAL, n.v.).

In transferring the Thai Kaempferia macrochlamys Baker to Stahlianthus O. Kuntze, Craib remarked 'To Stahlianthus also belong $K$. involucrata and probably $K$. andersonii: He did not make formal combinations. 
This small genus of perhaps half a dozen species has a distribution ranging from $\mathrm{N}$ Thailand to Indo-China and the Himalaya; it may also occur in the Philippines. It is distinguished from Kaempferia by the conspicuous bell-like involucre which surrounds the inflorescence, the emarginate or only shortly bifid labellum and, fide Kuntze, the absence of epigynous glands. No recent collections have been seen and inflorescences, either living or preserved in alcohol are badly needed since their structure is poorly known. 